$$
\begin{gathered}
\text { プリンタのキャリッジのスティックスリップ挙動 } \\
\text { に及ぼす表面形状の影響 }
\end{gathered}
$$

\title{
Effect of Surface Topography on Stick-slip Motion of the Printer Carriage
}

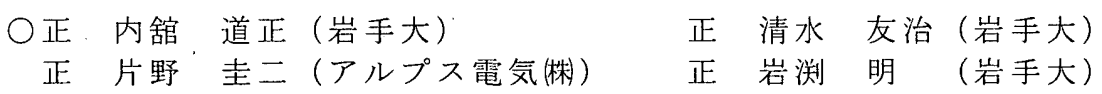

Michimasa UCHIDATE, Iwate University, Ueda 4-3-5, Morioka-shi, Iwate

Tomoharu SHIMIZU, Iwate University

Keiji KATANO, Alps Electric Co., Ltd., 50 Aza, Kami-imoda, Tamayama, Iwate

Akira IWABUCHI, Iwate University

Keywords: Thermal Serial Printer, Stick-slip Motion, Jitter, Simulation, Surface Roughness, Surface Waviness

\section{1.はじめに}

シリアルプリンタのさらなる高解像度化を実現す るための重要課題の一つは, キャリッジのスティッ クスリップによるジッタ（濃淡のむら）である.

著者らは，これまでキャリッジシステムをモデル 化した実験を行い，軸の表面形状のう㸚り成分がス ティックスリップ挙動に影響を及ぼすことを明らか にしてきた。

本研究では, 軸と軸受の三次元表面形状を考慮し たスティックスリップのシミュレーションを行い， 軸の表面形状がスティックスリップ現象に与える影 響を詳細に検討する。

\section{2. プリンタキャリッジのモデル化}

キャリッジの機構は，Fig.1のように表される，す ベり軸受は左右に 2 つあり, 摺動面の材料はガラス 繊維強化のエンジニアリングプラスチックである。 また，シャフトの材質は，快削鋼である。キャリッ ジは，タイミングベルトによって左右に駆動される. このキャリッジの挙動の運動方程式を, 次式とする.

$$
m \ddot{x}+c(\dot{x}-v)+k(x-v t)=F
$$

ここで， $x$ はキャリッジの位置， $v$ は駆動速度， $k$ は ばね定数, $c$ は粘性減衰係数, $m$ はキャリッジ質量, $F$ は摩擦力である。

\section{3. 計算方法}

\section{1 接触解析}

接触解析には, 軸と軸受の表面形状より接触領域 を求め, その接触領域の個々の接触点に対しヘルッ 接触を適用する方法を用いた。さらに軸受の位置を 軸方向に移動させ，それぞれの位置における接触状 態を求めた。ここで, 軸と軸受のヤング率はそれぞ れ $200 \mathrm{GPa}, 5 \mathrm{GPa}$, ポアソン比はどちらも 0.3 とし た。以上のような計算によって求められた真実接触

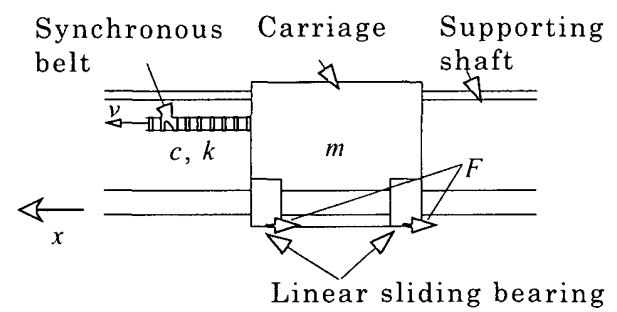

Fig.1 Schematic diagram of the carriage driving system
面積に，実験より求められた摩擦係数となるように 凝着部せん断応力を掛け合わせ，それぞれの位置に おけるFの值とした。

\section{2 スティックスリップ挙動解析}

スティックスリップ挙動は，式（1）によって計算 される。ここでは, 式（1）の数值解法には 4 次のル ンゲ・クッタ法を適用した。式（1）のパラメータは， $v=5.08 \times 10^{-2} \mathrm{~m} / \mathrm{s}, \quad k=4.70 \times 10^{4} \mathrm{~N} / \mathrm{m}, \quad c=17.0 \mathrm{Nm} / \mathrm{s}$, $m=0.465 \mathrm{~kg}$ とした。また， $F$ は接触解析の結果より求 められた值であり，場所による変動を考慮する。な お，速度による摩擦係数の変動は小さいものと考え， 考慮していない。

\section{4. 軸と軸受の表面形状}

本研究では，軸の表面形状がスティックスリップ 挙動に与える影響を検討するため，非因果的二次元 自己回帰（2-D AR）モデルによって種々の特徵を有 した三次元表面形状データを創成し，シミュレーシ ヨンに用いた。

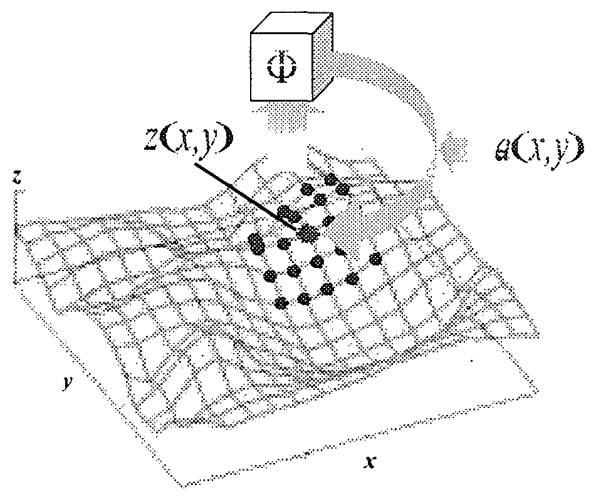

Fig.2 Schematic diagram of the non-causal 2-D AR model

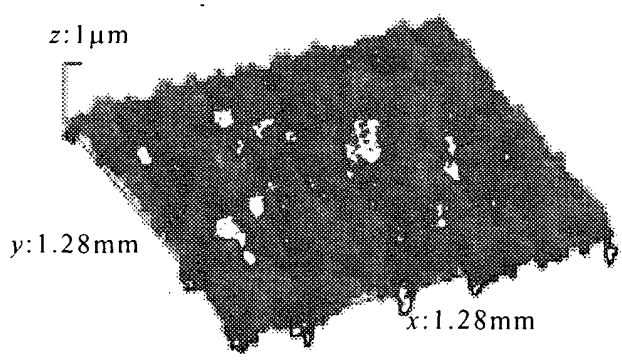

Fig.3 Generated surface roughness for the shaft 


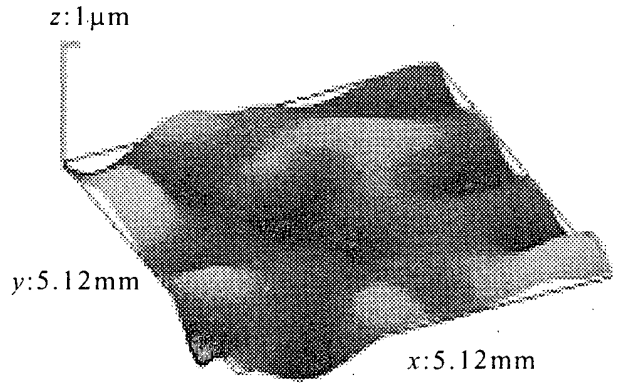

(a) $\beta=0.4 \mathrm{~mm}$

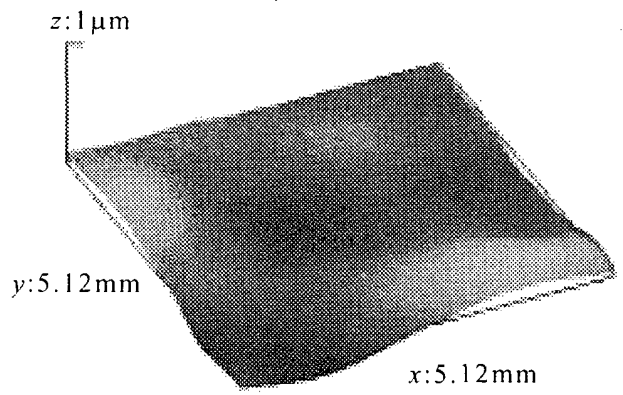

(b) $\beta=1.0 \mathrm{~mm}$

Fig.4 Generated waviness component for the shaft
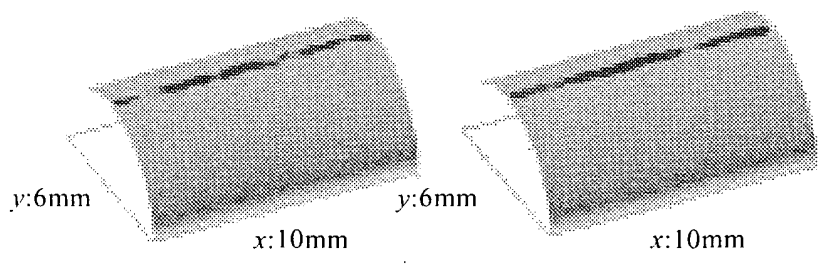

(a) $\beta=0.4 \mathrm{~mm}$

(b) $\beta=1.0 \mathrm{~mm}$

Fig.5 Contact points from the contact analysis results

三次元表面形状を $\left\{z_{x y}\right\}$ とするとき，非因果的 2-D AR モデルは,

$$
\begin{gathered}
z_{x y}=\sum_{(i, j)} \sum_{\in D} \phi_{i j} z_{x-i, y-j}+a_{x y} \\
D=\{(i, j) \mid-m \leq i \leq m,-n \leq j \leq n,(i, j) \neq(0,0)\}
\end{gathered}
$$

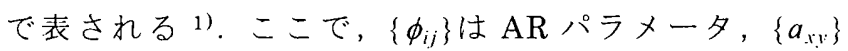
は表面形状の不規則性を表すノイズ成分， $m, n$ は $\mathrm{AR}$ の次数である。このモデルの概念図をFig.2に示す。 この表面形状モデルによって種々の特徵を有した三. 次元表面形状デー夕を創成した 2).

軸の表面形状は，短波長成分の粗さと長波長成分 のうねりをカットオフ長さ $1 \mathrm{~mm}$ のガウシャンフィル ターで分離して取り扱った。Fig.3に創成された粗さ 成分を示す。この粗さ成分は, 実際の軸の表面形状 をモデル化して創成されたものであり， $\mathrm{Ra}=0.12 \mu \mathrm{m}$ である。また，Fig.4には創成されたうねり成分の三 次元表面形状の例として，(a) $\beta=0.4 \mathrm{~mm}$ と (b) $\beta=1.0 \mathrm{~mm}$ ( $\beta$ : 相関距離) の表面形状を示す。これらは算術平 均粗さWaはともに約 $63 \mathrm{~nm}$ であるが, うねりの波長 が異なる。軸の表面形状は粗さ成分とう的り成分の 和とした。また, 解析においては, 軸と軸受のクリ アランス $90 \mu \mathrm{m}$ とし, クリアランスによる曲面を足 し合わせシミュレーションに用いた。

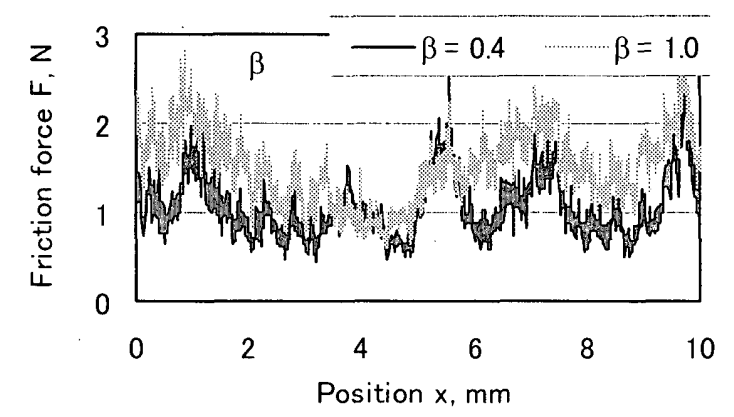

Fig.6 Friction force calculated from the contact analysis results

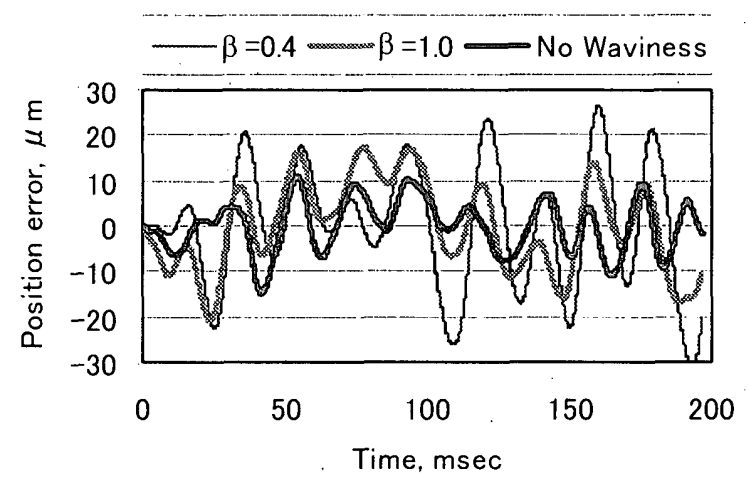

Fig.7 Simulation results of position error

軸受の粗さ成分については, 軸と同様に类測の表 面形状に非因果的 2-D AR モデルを適用して創成し た。ただし，軸受のうねり成分については実測の形 状より測定された中央付近のくぼみを考慮した表面 形状とした。

\section{5. 解析結果}

接触解析によって求められた接触点をFig.5 示す. 円筒形状の上部の点が, 軸上の接触点を示している. 接触点の分布のかたよりが，うねりによってもたら されていることがわかる.Fig.6に接触解析の結果よ り計算された摩擦係数の変動を示す. 粗さによる周 期の短い変動とうねりによる長周期の変動が見られ る.また, $\beta=0.4 \mathrm{~mm}$ と $\beta=1.0 \mathrm{~mm}$ の場合では, うねり による変動の周期が異なる.Fig.6の摩擦力の変動を 考慮に入れた，スティックスリップによる変位誤差 のシミュレーション結果を Fig.7に示す.比較のため, 軸のうねりがない場合も同図に示す。粗さによる短 い周期の変動はほとんど見られず, おもにうねりに よってスティックスリップ挙動が大きく異なること が示されている。

\section{6. まとめ}

本研究では，プリンタキャリッジの軸と軸受の表 面形状の影響を考慮したスティックスリッブ挙動の シミュレーションを行った。その結果, 軸のうねり 成分の波長がその挙動に大きな影響を及ぼすことが 示された。

\section{参考文献}

1）清水友治・内舘道正・岩㴊明, トライボロジスト, 45,6 (2000) 177-483.

2) Michimasa Uchidate, Tomoharu Shimizu and Akira Iwabuchi, Proc. Int. Tribol. Conf. Nagasaki 2000(Now Printing). 